\title{
El verdugo de Honoré de Balzac. Sobre Espańa, el secreto y las cabezas cortadas
}

\author{
Maria Zerari \\ Sorbonne Université
}

Título: El verdugo de Honoré de Balzac. Sobre España, el secreto y las cabezas cortadas.

Resumen: El verdugo (1830) de Honoré de Balzac es un relato corto cuya trama seudo-histórica no deja de fascinar. Así, el ámbito de la guerra de la Independencia espańola abarca una terrible historia de cabezas cortadas, de una noble dinastía ejecutada por uno de sus miembros, a fin de salvar la honra. Este relato encierra, de manera más o menos solapada, la historia íntima, y un punto turbia, de una familia ficticia, la cual parece sugerir algo acerca de la secreta historia de la de Balzac e incluso sobre el mismísimo Honoré.

Palabras clave: El verdugo, España negra, España heroica, siglo XIX, Balzac.

Fecha de recepción: 15/8/2020.

Fecha de aceptación: 21/9/2020.
Title: El Verdugo of Honoré de Balzac. About Spain, the Secret and Decapitation.

Abstract: Honoré de Balzac composed El Verdugo in 1830 , a short story whose pseudo-historical plot continues to fascinate. Thereby, the context of the war of Spanish independence encompasses a terrible story of cut off heads of a noble dynasty executed by one of its members, in order to save the honor. The short novel covers, in a more or less overlapping way, the intimate and murky story of a fictional dynasty, which seems to suggest something about the secret history of the Balzac family, and even about Honoré himself.

Key words: El Verdugo, Black Spain, Heroic Spain, $19^{\text {th }}$ Century, Balzac.

Date of Receipt: 15/8/2020.

Date of Approval: 21/9/2020.

Dentro de La Comedia humana (1829-1850) o del muy francés "planeta Balzac", por tomar prestada al François Mauriac de Galigaï una fórmula exitosa, se incluye un relato temprano, titulado El verdugo (1830), que es uno de los más cortos de su monumental producción. Pese a su sencillez, el título del relato no deja de ser extraño para el lector francés —al 
menos para el que desconoce la lengua del maestro- , por venir escrito, evidentemente, en castellano. El texto, cuyo arranque paratextual anuncia una materia española, apenas ha llamado la atención de los hispanistas ${ }^{1}$, si bien, en el ámbito propiamente balzaciano, un puñado de críticos y escritores le han otorgado cierta importancia ${ }^{2}$. Sin embargo, este texto seudo-histórico, de cautivador ambiente, parece pertenecer a aquellas "miniaturas" novelescas, tan eficaces, que el Proust lector de Balzac solía ensalzar ${ }^{3}$. El verdugo, texto de índole trágica, pinta en una decena de

1 En su primera versión, este trabajo fue presentado en la Escuela Normal Superior de París (seminario hispánico del 14 de enero de 2010) y, el 28 de noviembre de 2012, en el Centro del Carmen de Valencia (jornada sobre "La mirada francesa: Balzac, Victor Hugo y Flaubert", en colaboración con el Consorcio de Museos, la Agencia Consular de Francia y el Instituto Francés). Se publicó, en el verano 2012, en el primer número (dedicado a la temática del secreto) de la revista Iberic@l (revista en línea del "Crimic" de "Sorbonne Université"). Agradecemos a Nancy Berthier, fundadora y directora de la revista, la posibilidad de publicar esta versión revisada y traducida al castellano, así como a Rafael Bonilla Cerezo su generosa acogida y gran ayuda. Exceptuando las citas de El Verdugo (nótese que, a diferencia de lo que ocurre en su traducción, el título francés pone en mayúscula la palabra clave "verdugo"), el resto de las traducciones son nuestras.

Jean Sarrailh ha sido uno de los primeros en dedicar algunas líneas a El verdugo. Véase su artículo "Sur quelques histoires espagnoles de Balzac", en Estudios hispánicos. Homenaje a Archer M. Huntington, Wellesley, Massachusetts, Wellesley College, 1952, pp. 529-540.

2 Si los balzacistas se han interesado por este relato de manera somera, Pierre Citron, gran conocedor de literatura francesa, y Michel Butor han examinado con cierto detalle El verdugo. Véanse al respecto Victor L. Leathers, L'Espagne et les Espagnols dans l'euvre d'Honoré de Balzac, París, Honoré Champion, 1931, pp. 46-49; Pierre Citron, "Introduction", La Comédie humaine, París, Gallimard, "Bibliothèque de la Pléiade", 1979, t. X, pp. 1123-1143; Michel Butor, "Trois nouvelles espagnoles de Balzac", Thélème, Revista Complutense de Estudios Franceses, 13 (1998), pp. 219251. Véanse también, Janet Beizer, Family Plots. Balzac's Narrative Generations, New Haven-London, Yale University Press, 1986, pp. 15-47; Max Andréoli, "El Verdugo, ou l'antithèse tranchée”, L'École des lettres, 13 (1998-1999), pp. 90-92; y Owen Heathcote, "Aux sources de Balzac: violence et philosophie dans Sténie et El Verdugo", L’Année balzacienne, 7 (2006), pp. 17-37.

3 En su correspondencia, Marcel Proust alaba algunas de las novelas cortas de Balzac, explicando que el arte de la "miniatura" puede igualar al del "fresco". Véase JeanYves Tadié, "Proust, lecteur de Balzac", L'Année balzacienne, 14 (1993), pp. 311 320. Zweig, por su parte, clasificó El verdugo entre las "obras maestras de pequeño 
páginas a una gran familia de la Península sumida en la tormenta de lo que, de un lado de los Pirineos se ha llamado la guerra de la Independencia, y del otro, la guerra de Espańa (1808-1814).

A buen seguro, fueron el tinte histórico y las reverberaciones políticas del relato los que hicieron que "El Verdugo" se tradujese al castellano, publicándose en 1848, en El Semanario Pintoresco Español, a través de una adaptación que buscaba dotar de mayor heroísmo a los españoles y ensombrecer a los protagonistas franceses ${ }^{4}$. Sea como fuere, y dejando aparte el liberalismo anti-bonapartista que se entrevé en la historia, son principalmente las implicaciones fantasmagóricas del relato y su relación con la temática del secreto ${ }^{5}$ las que han despertado nuestro interés por este cuento cruel, de veras rico en lazos subterráneos con otras obras de Balzac.

Mediante una lectura algo oblicua, aunque guiada por el hilo conductor del secreto, hemos evocado la imagen de la singular España que dibuja El verdugo: la de un país a la vez tópico y especial, predecible y de gran extrañeza, además de mitológicamente tenebroso, viva imagen de su pueblo, según los idearios antiguos. La aprehensión de esa España mitológica, en el sentido que le dio Roland Barthes a dicha palabra ${ }^{6}$, ha favorecido el examen de otra patria aún más secreta: esa comunidad, señaladamente ilustre y simbólicamente oscura que constituye, en El verdugo, la familia Leganés. Por fin, ya que una dinastía puede encubrir a otra, pasando del marco de la ficción al de lo biográfico o, dicho de otro modo, de las cabezas cortadas a los "fantasmas" del pasado autorial, algunas huellas del roman des origines de Honoré de Balzac han sido designadas como otros tantos secretos de Polichinela.

formato" de Honoré de Balzac. Vid. Stefan Zweig, Balzac, le roman de sa vie (1946), trad. Fernand Delmas, París, Albin Michel, "Le livre de poche", 2010, p. 127.

4 Sobre la primera adaptación espańola de El Verdugo, véase Lídia Anoll i Vendrell, "El Verdugo de Balzac dans la presse périodique espagnole du XIX siècle", Revue de Littérature Comparée, 3 (1985), pp. 291-297.

5 Es preciso recordar que este artículo se desarrolló primero en un volumen monográfico sobre el secreto en el ámbito literario, de ahí su principal temática. Véase la versión francesa en Le secret, Iberi@l, dirs. Sadi Lakhdari e Irina Enache Vic, 1 (2012), pp. 31-41.

6 Véase Roland Barthes, Mythologies, París, Ed. du Seuil, 1957. 


\section{Paratexto y argumento}

Antes de formar parte del segundo tomo de las Novelas y cuentos filosóficos (Romans et contes philosophiques, edición Gosselin, 1831), del quinto tomo de los Estudios filosóficos (Études philosophiques, edición Werdet, 1835) y, finalmente, del tomo XV de La Comedia humana (edición Furne, 1846), con fecha de redacción oficial de "octubre 1829", el "cuento" titulado El Verdugo se publicó el 30 de enero de 1830 en la revista La Mode L Aunque $^{\circ}$ no nos ocupemos en este trabajo de la cuestión genérica, es interesante observar que, al principio, El Verdugo fue considerado por su autor como un "cuento filosófico", lo que supone una forma y un fondo peculiares ${ }^{8}$, granjeándose las críticas de quienes no vieron en los "cuentos filosóficos" ni "cuentos" ni filosofía. Según las indicaciones de Pierre Citron", en su versión original el texto tenía como antetítulo Souvenirs soldadesques, y como subtítulo Guerre d'Espagne (1809). Dicho armazón acabó por aligerarse y, de acuerdo con el "Catálogo de las obras de La Comedia humana" ("Catalogue des ouvrages que contiendra La Comédie humaine") 10, es bajo el título de El Verdugo, y con mayúscula, como Balzac había previsto insertar su relato en la segunda parte de su obra tripartita, compuesta por Études de moeurs (Estudios de los modales), Études philosophiques (Estudios filosóficos) y Études analytiques (Estudios analíticos). En la edición de 1846, Balzac se lo dedicó "A [Francisco] Martínez de la Rosa”, escritor, político y diplomático español, de gran valía patriótica, que se sumó a las filas de

7 La revista La Mode, fundada en 1829 por el gran hombre del periodismo Émile Girardin, trataba de moda y de literatura. Según los historiadores de la prensa, a partir de 1831, en nombre de un ferviente legitimismo, La Mode no dejó de tomar parte en el debate político, atacando violentamente a Louis-Philippe.

8 Sobre la compleja cuestión de los primeros "cuentos" de Balzac y el tema del Balzac cuentista, véase Michiaki Tanimato, La figure du conteur chez Balzac, tesis doctoral bajo la dirección del profesor José Luis Diaz, leída en Sorbonne Paris Cité, el 24 de septiembre 2016.

9 Véase Honoré de Balzac, El Verdugo, en La Comédie humaine (Études philosophiques), ed. Pierre-Georges Castex, París, Gallimard, "Bibliothèque de la Pléiade", 1979, t. X, p. 1816. Es la edición que hemos utilizado para este artículo. En dicha edición, el texto El Verdugo lo presenta y anota el profesor Pierre Citron.

10 Véase Honoré de Balzac, La Comédie humaine, ed. Pierre-Georges Castex, París, Gallimard, "Bibliothèque de la Pléiade", 1976, t. I, p. CXXV. 
los revolucionarios liberales durante la guerra de la Independencia y, al estallar el conflicto, trató de negociar la ayuda inglesa ${ }^{11}$. Por otra parte, en materia de paratexto, conviene subrayar otro hecho esencial: el que Balzac, gran forjador de nombres y seudónimos ${ }^{12}$, firmase esta obra con un significativo "H. de Balzac", según examinaremos a continuación.

Título abiertamente enigmático —que bien poco suena a un lector que no sea hispanófilo, el cual, por acercamiento fónico con la voz francesa bourreau, hubiera podido entender, como mucho, el arcaico "borrero"13_, si El verdugo no es el único título de Balzac a la vez sugestivo y peculiar, e incluso algo misterioso ${ }^{14}$, es, de seguro, el único de La Comedia humana escrito en español. Lacónico y sonoro, el título El verdugo le confiere una rudeza, una tosca singularidad, al texto que encabeza. Desde un principio, plantea una especie de enigma y, al mismo tiempo, anuncia los colores del relato. Son colores nacionales, son colores locales, mas con una impactante mezcla de rojo y negro. El verdugo cuenta en efecto las sangrientas consecuencias de una revuelta contra el ocupante francés durante la campaña napoleónica en suelo español, en los primeros ańos de la contienda. Esta es, en esencia, la tremebunda trama: tras un sublevamiento encabezado por los miembros de una gran familia de Espańa, a modo de represalias, los líderes de la revuelta - a saber: el marqués de Leganés y los suyos— serán condenados a muerte por el desalmado general G..t..r. La intervención del oficial francés Víctor Marchand solo permitirá el indulto de Juanito, primogénito de la familia Leganés, además de la decapitación de la noble prole hispana, en lugar del infame ahorcamiento. Pero, según la inhumana idea del sádico G..t..r,

11 Sobre esta figura histórica, véase el trabajo pionero de Jean Sarrail, Un homme d'État espagnol: Martínez de la Rosa (1787-1862), Poitiers, Nicolas Renault et Cie, 1930. Véase también Pedro Pérez de la Blanca Sales, Martínez de la Rosa y sus tiempos, Barcelona, Ariel, 2005.

12 Respecto a esta cuestión crucial, véase Michiaki Tanimoto, "L’art de la mystification chez Balzac: anonymat, pseudonymat, titre trompeur", texto en línea.

13 "Borrero. (Del francés bourreau). sustantivo masculino, anticuado. Verdugo, ejecutor de justicia”, Real Academia Espańola, Diccionario de la lengua española, 2 vols., Madrid, Espasa Calpe, 1992, I, p. 313.

14 En lo tocante a la oscuridad, al carácter enigmático y hasta misterioso de ciertos títulos balzacianos, como por ejemplo el de Sarrasine, véase Roland Barthes, $S / Z$ (1970), París, Ed. du Seuil, "Points", 1976, p. 24. 
la decapitación tendrá lugar bajo la condición de que el hijo sirva de ejecutor de la justicia. Animado por su padre, el marqués de Leganés, Juanito acepta decapitar a todos sus familiares, convirtiéndose así en "El verdugo" por antonomasia. Por encima del entramado, ese es el novelesco argumento, harto eficiente, de un relato narrativamente marginal "con respecto al tipo", en acertada opinión de Julien Gracq ${ }^{15}$; puesto que, a través de la elipsis y de lo implícito, El verdugo progresa omitiendo los amplios y precisos desarrollos de los relatos balzacianos más canónicos.

\section{ESPAÑA: "UN PAÍS SINGULAR"}

La acción, arraigada en un contexto histórico, tiene como marco geográfico un espacio delimitado, aunque imaginario, que se presenta desde el íncipit: "Le clocher de la petite ville de Menda venait de sonner minuit"16 ("El campanario de la pequeña ciudad de Menda acababa de dar la medianoche") ${ }^{17}$. Se introduce así con eficacia el lugar común, forjado en el XVIII y retomado por los escritores románticos de una España tan cristiana como nocturna, es decir, potencialmente peligrosa: el escribir "minuit" en francés es casi anunciar la hora del crimen. No obstante, el lugar aparentemente ameno, del cual se menciona de manera normativa "le beau ciel d'Espagne" ("el hermoso cielo de España") atravesado por "le scintillement des étoiles" ("el centelleo de las estrellas") y "la douce lumière de la lune" ("la suave luz de la luna"), no es más que un espacio del secreto. En efecto, en las alturas de tan agradable ciudad, coronada por un "chateau illumine" ("un castillo iluminado") ardiendo en fiestas, el viejo marqués de Leganés ha urdido una insurrección. Es en la ciudad de Menda, que corresponde histórica y geográficamente a la ciudad de San-

15 Julien Gracq, En lisant en écrivant, Paris, José Corti, 1980, p. 22.

16 Honoré de Balzac, El Verdugo, op. cit., p. 1133.

17 Citaremos el texto en su lengua original y en traducción española. La versión francesa es la de la colección de la Pléiade (El Verdugo), edición de referencia ya citada, y la traducción utilizada (El verdugo) se registra en la siguiente edición: Honoré de Balzac, El coronel Chabert seguido de El verdugo, El elixir de larga vida, La obra maestra desconocida, trad. Mercedes López-Ballesteros, Barcelona, Reino de Rondo, 2011, pp. 109-123 (p. 109). 
tander, con su antigua fortaleza, su ciudad alta y su ciudad baja, donde una revuelta fomentada por los lugareños está a punto de estallar. Menda, ciudad imaginaria que, en una neblina típicamente balzaciana, lleva el topónimo real de una aldea de Galicia, se transforma de repente en una suerte de locus terribilis.

En medio de una noche apacible en la que se celebra un baile en el castillo, el descubrimiento de unas luces por el joven oficial Víctor Marchand en la ciudad baja, a pesar de su prohibición durante la noche de Santiago, desemboca en una serie de eventos desastrosos: la localización por el militar de las velas de un barco enemigo; el asesinato de un soldado francés; la persecución de Marchand por los hijos del marqués; su huida gracias a la intervención de Clara, la hija del aristócrata; el aplastamiento de la rebelión española, y las sangrientas represalias de los franceses. De modo que, a través de los ojos de Víctor Marchand, ya que el narrador omnisciente usa a menudo la focalización interna, el lugar se convierte en un espacio inquietante en el cual reina un "misterio" [sic], algo escondido que acababa por ser descubierto: las velas de un buque en el océano, signo evidente del temido desembarco de los ingleses, prueba manifiesta de una conspiración y de una alianza política a favor de Fernando VII y, por otra parte, recuerdo de los intentos de desembarco británicos en la costa norte de España en los años 1808-1809. Una vez aclarado el misterio, hasta el final del relato el lugar de la acción viene a ser habitado por la violencia y la muerte, tanto fuera como dentro del castillo. Y la aparente tregua, la afabilidad del marqués para con Víctor Marchand y sus soldados, así como la inclinación amorosa de Víctor y de Clara, todo ello termina por dar paso al odio de los dos bandos presentes, "les Français" y "les Espagnols", esto es, los franceses y los españoles, según una terminología recurrente en el texto que solo parece considerar a los personajes en función de su nacionalidad, lo que sugiere una sustancial y radical alteridad. Dicho fenómeno es recalcado por las necesarias mayúsculas, en francés, de los sustantivos "Français" y "Espagnols", de modo que los vocablos parecen figurar una severidad gráfica, e incluso una tipográfica agresividad.

El relato, que desde la tercera página del texto se resume en una suma de tensiones, utiliza la imagen, ya conocida y difundida por el Romanticismo francés - a partir de Prosper Mérimée (con el Teatro de Clara Gazul, 1825) y de Victor Hugo (con Hernani, 1830)_, de una 
España sombría e impenetrable, de un país hermético y violento que otros escritores más tardíos seguirán evocando ${ }^{18}$. En realidad, la España de Balzac y de numerosos autores del siglo XIX — síntesis "literaturizada” de una Andalucía retrasada, algo salvaje (y, no obstante, atrayente) descrita por los viajeros ingleses y galos a partir de la segunda mitad del siglo $\mathrm{XVIII}^{19}$ —, es sobre todo un territorio diferente, exótico, más oriental ${ }^{20}$ que europeo, más arcaico que moderno, más bien "inculto y fanático" ${ }^{21}$, misterioso y extrañamente inquietante. En resumidas cuentas, se trata de "un país singular", por retomar la etiqueta de La musa del departamento $(1847)^{22}$. En el texto que nos interesa, España se asemeja a un espacio del silencio y del secreto, a la vez cercano (geográficamente) y lejano (moral y espiritualmente), donde el sentido del honor cierra las bocas y dicta las conductas hasta la muerte.

18 Sobre la España "negra" en las letras francesas del siglo XIX, véanse, principalmente, Yves Avril, "L'Espagne de Barbey d'Aurevilly”, Études littéraires, II, 1 (1969), pp. 33-55, y Wilfried Floeck, "Victor Hugo et l'Espagne", Francofonia, 13 (1987), pp. 87-102.

$19 \mathrm{Al}$ respecto, véanse Antonio López Ontiveros, "Caracterización geográfica de Andalucía según la literatura viajera de los siglos XVIII y XIX”, Ería, 54-55 (2001), pp. 7-51; y Esther Ortas Durand, "La Espańa de los viajeros (1755-1846): imágenes reales, literaturizadas, sońadas", en Los libros de viajes: realidad vivida y géneros literarios, coords. Patricia Almarcegui Elduayen y Leonardo Romero Tobar, Madrid, Akal, 2005, pp. 48-91.

20 Notemos, como escribe Rose Fortassier, que el Oriente balzaciano es "inmenso e impreciso". Se extiende "desde las Indias Occidentales hasta las Indias Orientales, y desde China hasta México, pasando por Georgia, Venecia, Holanda y España” (Hemos traducido el pasaje). Vid. Rose Fortassier, "Introduction", en La Comédie humaine, ed. Pierre-Georges Castex, París, Gallimard, "Bibliothèque de la Pléiade", 1977, t. V, pp. 737-786 (p. 778). Sobre el Oriente en La Comedia humana, véase también, Pierre Citron, "Le rêve asiatique de Balzac", L’Année balzacienne, París, PUF, 1968, pp. 303-336.

21 Recordemos que en el siglo ilustrado y en el siguiente "España representaba para la intelectualidad europea un país inculto y fanático, acusando muchos de ellos a la Iglesia española de su retraso" (Félix Pillet Capdepón, "Viajeros por los paisajes de Espańa: del siglo XVIII a la actualidad”, Cuadernos de Turismo, 38 (2016), pp. 361-383 (p. 362)).

22 "L'Espagne est un singulier pays, dit Mme de La Baudraye, il y reste quelque chose des moeurs arabes" ("España es un país singular, dijo la Señora de La Baudraye, aún queda allí algo de las costumbres árabes"), en Honoré de Balzac, La Muse du département, ed. Patrick Berthier, París, Gallimard, "folio classique", 1984, p. 110. 
Como se verifica también en Los Marana (1834), para Balzac el marco de la guerra de Espańa es uno de los soportes en el que algunos de sus personajes sobresalen idealmente. A decir verdad, en materia de fondo negro, el escritor no podía encontrar marco mejor, o más bien peor, que la guerra de España. En palabras de Napoleón, esa maldita guerra fue una "verdadera plaga" y, según los dichos de los memorialistas, una pesadilla, de la que dan testimonio Los desastres de la guerra de España de Goya, la famosa serie de grabados producida, precisamente, "entre 1810 y 1820 en el secreto del taller" 23 . País austero, atrasado y salvaje, la España de El verdugo es una España de convención cuyo arcaísmo posee el tinte de la leyenda negra, y de esas "imágenes reales" y "soñadas" señaladas por la crítica. Esta España "negra”, en su acepción goyesca, se presenta también como una patria sumamente heroica ${ }^{24}$ que posee un sentido del honor extremado. Es más, se la describe como el último bastión de la antigua, ilustre y esforzada aristocracia frente a una Francia posrevolucionaria, bastante vil y demasiado burguesa, cuya personificación toma cuerpo en el innoble general G..t..r y en el muy burgués Víctor Marchand (marchand significa en francés "mercader"), a pesar de la nobleza moral que caracteriza a este sujeto.

\section{Perfiles españoles}

A excepción del francés Víctor Marchand, en semejante contexto el relato pone de relieve a los protagonistas españoles, a la familia Leganés, un clan altamente aristocrático, si tomamos en cuenta la mencionada "grandeza"

23 Tomamos la expresión a Jean-Philippe Chimot, "Les désastres de la guerre", Amnis, [en línea], 6 (2006), puesto en línea el 01 de septiembre de 2006, http://amnis. revues.org/900.

24 Sobre este "negativo de la leyenda negra", véase Jean-Marc Lafon, "L'impact littéraire de la guerre d'indépendance espagnole en France aux XIX et XX ${ }^{e}$ siècles", Bulletin hispanique, 103, 2 (2001), pp. 543-562. Véanse también Jesús Villanueva, Leyenda negra. Una polémica nacionalista en la España del siglo XIX, Madrid, Libros de la Catarata, 2011, y Antonio Sánchez Jiménez, "La Leyenda Negra: para un estado de la cuestión”, en España ante sus criticos: las claves de la Leyenda Negra, eds. Yolanda Rodríguez Pérez, Antonio Sánchez Jiménez y Harm den Boer, IberoamericanaVervuert, Madrid-Frankfurt, 2015, pp. 23-44. 
del marqués ${ }^{25}$. Esta familia, que lleva un título históricamente probado (no en Cantabria sino en Castilla), y del que conocemos, bajo el reino de Felipe IV, el histórico primer marqués ${ }^{26}$, se compone, además de un padre y de una madre, de tres hijos y dos hijas. Ahora bien, en el seno de dicho linaje, cuatro figuras se distinguen: los padres y los hermanos mayores, Juanito y Clara. Este grupo viene dominado por la figura del padre. El marqués, a pesar de su edad avanzada, es el pater familias o el macho dominante. Se trata de un progenitor absoluto, imperioso, duro y enérgico, que dicta su ley y a quien todos obedecen, empezando por Juanito, el primogénito. Este hijo, lo sabemos, se ve obligado a cumplir las órdenes del padre y, por consiguiente, acepta decapitar tanto a su padre como al resto de su familia, para conservar el nombre de su estirpe. En cierto modo, tales relaciones padre-hijo, fundadas en la potestas paterna, bien podrían encontrar su glosa en la tesis darwiniana de los orígenes comentada por Sigmund Freud en Tótem y tabú (1913), aunque Juanito mate al padre despótico contra su voluntad, al menos, consciente, a diferencia de la horda primitiva. De manera subrepticia, el relato deja entrever los lazos que unen a los miembros de la ilustre familia. En el clímax del texto, justo cuando Juanito tiene que decapitar a todos los suyos, frente al desconcierto del joven, y a cuenta de la urgencia de la situación, las lenguas del padre y de la hermana se desatan, dejando escapar secretos muy íntimos con transgresivo cariz de alcoba. Y es que, para animar a su hermano en su terrible tarea, para que Juanito cumpla el inhumano contrato establecido por el muy sádico general francés y aceptado por el inflexible pater familias, Clara actúa y habla con este último como si fuera una mujer frente a su amante:

Mon cher Juanito, dit-elle en lui passant le bras autour du coup et en l'embrassant sur les paupières; si tu savais combien donnée par toi,

25 "[...] la fille du vieillard le plus entiché de sa grandesse qui fût en Espagne" ("la hija del anciano más apegado a su grandeza que jamás hubo en España”, trad. cit., p. 110), Honoré de Balzac, El Verdugo, op. cit., p. 1134.

26 Respecto al I marqués de Leganés, quien, salvo el título, nada tiene que ver con el personaje balzaciano de El verdugo, véase Francisco Arroyo Martín, "El marqués de Leganés. Apuntes biográficos”, Espacio, Tiempo y Forma, Serie IV, 15 (2002), pp. 145-185; y, del mismo autor, El marqués de Leganés. El favorito del valido, Madrid, Sílex, 2018. 
la mort me sera douce. Je n'aurais pas à subir l'odieux contact des mains d'un bourreau. Tu me guériras des maux qui m'attendaient, et... mon bon Juanito, tu ne voulais me voir à personne, eh bien ? ${ }^{27}$

La pasión erótica — pasión balzaciana por excelencia— brota de las frases de Juanita. Lo entendemos, la futura muerte dada por el hermano mayor es abiertamente concebida como un alivio, una suave y mortal caricia $y$, su concreción, como una muerte chiquita, en términos españoles, y casi como una especie de petite mort, en términos franceses, o sea, como un orgasmo. De hecho, la relación exclusiva entre Juanito y su hermana es abordada aquí en su aspecto de celos eróticos y de incesto larvado (contra-sujetos del texto): según las palabras de Clara, el cuerpo de la hermana bien parece haber sido fantaseado por Juanito como un oscuro objeto de deseo, como algo prohibido a los demás y al rival francés Víctor Marchand, en particular. Al mismo tiempo, ya en la apoteosis de las decapitaciones, otros aspectos de la situación familiar salen a la luz. En efecto, ante la aparente pusilanimidad de Juanito, el padre pone en duda su propia paternidad haciendo una pregunta amarga y tajante, destinada tanto a la madre como al hijo: "C'est mon fils, madame ?” ("¿Es de veras mi hijo, señora?”) ${ }^{28}$. La sospecha de infidelidad materna apunta ahora, como en otros muchos textos de Balzac, mediante un posible eco del Mateo Falcone (1829) de Prosper Mérimée, relato en el cual brota una interrogación marital muy parecida: "Femme, cet enfant est-il de moi?" ("Mujer, ¡este niño es mío?”)29. Al final, el suicidio de la madre, ocasionado para ahorrarle al hijo una parte de su cruel trabajo, se presenta como la consecuencia de un amor filial que supera a todos los demás e inhibe al heredero, convertido en verdugo impotente. El “¡Ella me crió!”

27 Honoré de Balzac, El Verdugo, op. cit., p. 1140. "Mi querido Juanito —le dijo alegre, rodeándole el cuello con el brazo y besándolo en los párpados-, si supieras cuán dulce me será la muerte si eres tú quien me la da. No tendré que soportar el odioso contacto de las manos de un verdugo. Me curarás de los males que me habrían esperado y..., mi buen Juanito, tu no querías que no fuera de nadie, ¿̨no es así?" (Honoré de Balzac, El verdugo, trad. cit., p. 119).

28 Ibidem, p. 1140; trad. cit., p. 120.

29 Esta probable alusión ha sido señalada por Pierre Citron en la edición francesa de El verdugo que hemos manejado. Vid. Pierre Citron, "Introduction", en La Comédie humaine, X, op. cit., p. 1124. 
(“Elle m'a nourri!") ${ }^{30}$ que lanza un Juanito agobiado por su tarea y del todo desesperado frente a su querida madre, será el resorte del suicidio de la aristócrata. Y dicho suicidio se asemeja a un nuevo salto de Léucade, puesto que, por amor, la madre se precipita al vacío: "La marquise comprit que le courage de Juanito était épuisé, elle s'élança d'un bond par-dessus la balustrade, et alla se fendre la tête sur les rochers. Un cri d'admiration séleva. Juanito était tombé évanoui." ("La marquesa comprendió que el valor de Juanito se había agotado: se lanzó de un salto por encima de la balaustrada y se abrió la cabeza contra los riscos. Se alzó un grito de admiración. Juanito cayó desvanecido") $)^{31}$.

Juanito, paradójico héroe de la historia, muy meritorio cortador de cabezas, parricida por obediencia y no por rebelión, queda así señalado como personaje trágico; y es sabido que dicho personaje suele ser tan inocente como culpable, de ahí el carácter trágico de su naturaleza. En cualquier caso, Juanito, el dócil y desdichado ejecutor de la injusticia, el parricida sangriento $y$ heroico, guarda atisbos de misterio a lo largo de su trayectoria extremadamente romántica. Ténébreux, sombrío tanto mental como físicamente, es en puridad un héroe solitario y muy "secreto", al estar separado de todos los demás por un destino que le transforma en un ser único, absolutamente aparte. Por ańadidura, se trata de un protagonista taciturno, de pocas palabras, menos, quizás, por las terribles circunstancias en que se halla que por su esencia de "verdadero español", como precisa el narrador: es decir, de típico español, si tenemos en cuenta la tipología de las Naciones $^{32}$ reconducida por Balzac junto con su amigo Stendhal ${ }^{33}$. Efectivamente, el tópico del español grave y ensimismado por

30 Como es bien sabido, la palabra "secreto" viene del latín secretus. Secretus es el participio pasivo del verbo secernere, que significa poner aparte.

31 Honoré de Balzac, El Verdugo, op. cit., p. 1142; trad. cit., p. 122.

32 Véase Christine Orobitg, "La typologie des nations et l'Espagnol mélancolique: notes pour l'interprétation d'un cliché", Revue de synthèse, 1 (1995), pp. 99-128.

33 Según Stendhal, el carácter español es africano-oriental, arcaico y salvaje y se opone del todo al francés europeo, elegante y moderno: "Le caractère espagnol fait une belle opposition avec l'esprit français; dur, brusque, peu élégant, plein d'un orgueil sauvage, jamais occupé des autres: c'est exactement le contraste du XV siècle avec le XVIII siècle" ("El carácter español se opone perfectamente a la mente francesa; duro, brusco, poco elegante, lleno de un gran orgullo salvaje, nunca preocupado por el otro: forma exactamente el contraste del siglo XV con el siglo XVIII"). Véase Stendhal, 
ser melancólico, opuesto al del francés ligero y locuaz, de temperamento "colérico", encuentra aquí una perfecta encarnación. Al fin y al cabo, Juanito solo parece existir en el relato para ser, en sentido propio, el sombrío y sublime defensor del nombre del padre, pues la decapitación del marqués es lo que le permite al hijo conservar su hidalguía antes de que "el verdugo" se convierta en el verdadero título de nobleza del joven, según la voluntad del rey:

Malgré les respects dont il est entouré, malgré le titre d'El Verdugo (le Bourreau) que le roi d'Espagne a donné comme titre de noblesse au marquis de Léganès, il est dévoré par le chagrin, il vit solitaire et se montre rarement. Accablé sous le fardeau de son admirable forfait, il semble attendre que la naissance d'un second fils lui donne le droit de rejoindre les ombres qui l'accompagnent incessamment ${ }^{34}$.

Verdugo de los suyos, "hijo maldito" ("enfant maudit”), según el título de otro relato balzaciano ${ }^{35}$, por haber obedecido a la voluntad de su padre, por no haber querido ser ni un hombre débil ni "el fracasado de la familia" 36 y, en suma, por haber decapitado a toda su familia, al final termina siendo el fatal guardián de la memoria y de los secretos de su clan; un linaje del que lleva el duelo patológico como un héroe del Dark Romanticism atormentado por el peso de la culpa, el sabor a muerte y la sombra del suicidio.

“De l'Espagne”, en De l'amour (1822), París, Garnier-Flammarion, 1965, p. 172.

34 Honoré de Balzac, El Verdugo, op. cit., pp. 1142-1143. "Pese al respeto que se le profesa, pese al apelativo de El verdugo que el rey de España le ha otorgado al marqués de Leganés como título de nobleza, éste vive en soledad, devorado por la pena, y rara vez se muestra en público. Abrumado por el peso de su admirable fechoría, parece aguardar con impaciencia que el nacimiento de un segundo hijo le dé derecho a reunirse con las sombras que incesantemente lo acompañan" (Honoré de Balzac, El verdugo, trad. cit., p. 123).

35 Honoré de Balzac, L'enfant maudit (1831-1837), en La Comédie humaine, op. cit., X, pp. 865-960.

36 Tomamos la expresión del título francés de un afamado estudio norteamericano: Michael Lucey, Les ratés de la famille. Balzac et les formes sociales de la sexualité, traducido del inglés por Didier Eribon, París, Fayard, 2003. 


\section{Cabezas CORTAdas / FANTASMas / FANTASÍAS}

Este opúsculo tan breve y tan eficaz, que cuenta la historia de un verdugo en la línea de la corriente gótica o frenética, es de veras una pura historia de cabezas que se cortan y se pierden... la noche de Santiago Apóstol, o sea aquella en la que se celebra la fiesta del patrón de España, representado en las crónicas medievales como un matador de moros en la batalla de Clavijo y que, según la Biblia, murió decapitado por orden del rey de Judea, Herodes Agripa. Al decir del folklorista Alexander Haggerty Krappe, el tema del hijo verdugo de su padre a cambio de la salvación de su propia vida, proviene de una leyenda gantesa conocida por Balzac ${ }^{37}$. Con todo, el tema no resulta muy original, pues la literatura postrevolucionaria y el arte del siglo XIX en su conjunto rebosan de cabezas cortadas ${ }^{38}$. Balzac, en efecto, como otros muchos coetáneos, estuvo obsesionado por la decapitación de Luis XVI ${ }^{39}$, por las anécdotas relativas a los verdugos de la Revolución y, más aún, por la mismísima figura del ejecutor, como bien lo ilustran, en clave novelesca, Un episodio bajo el terror (1842) (relato que pone en escena a Charles-Henri Sanson, el ejecutor de Luis XVI) y, con un enfoque seudo-documental, Las memorias de Sanson (1829), en cuya redacción el escritor participó. Tras el

37 Alexander Haggerty Krappe, "La source flamande du conte El Verdugo d'Honoré de Balzac", Leuvense Bijdragen, 19 (1927), pp. 29-35.

38 Nótense las observaciones de Jean Clair, que traducimos literalmente: "Una de las imágenes más insistentes del siglo XIX fue la de una cabeza separada de su cuerpo. El tema de la cabeza cortada, sea histórico, religioso, o mitológico, parece haber dominado en efecto la iconografía del siglo: cabezas disecadas, cabezas de cera, cabezas moldeadas, cabezas esculpidas, grabadas, dibujadas y pintadas, cabezas de asesinos, cabezas de regicidas, cabezas de anarquistas, cabezas prototípicas de asesinos, de violadores, cabezas de políticos, cabezas de víctimas, cabezas de santos, cabezas de héroes o martirios, ¡cuántas cabezas cortadas!" ("Naissance de l'Acéphale", en Crime et châtiment, catálogo de exposición (Musée d'Orsay, 16 de marzo-27 de junio 2010), dir. Jean Clair, París, Gallimard, 2010, pp. 29-49 (p. 36)). Sobre el tema, véanse también Daniel Arasse, La guillotine et l'imaginaire de la Terreur, París, Flammarion, 1987; Patrick Wald Lasowski, Guillotinez-moi!, París, Gallimard, 2007; y Daniel Sangsue, "De quelques têtes coupées dans la littérature du XIX siècle", en Crime et châtiment, op. cit., pp. 75-83.

39 Sobre este particular, véase Roland Chollet, "Trophées de têtes dans La Comédie humaine", en À la lumière de Balzac (Études 1965-2012), París, Classiques Garnier, 2012, pp. 149-162. 
muy admirado y controvertido Joseph de Maistre — autor de Las Veladas de San Petersburgo (1821) — y sus laudatorias consideraciones sobre el verdugo en tanto que "piedra angular de las sociedades" y "misterio de la acción del poder divino", en tanto que "matador de profesión" "sin delito" y ser tan "extraordinario" e incomprensible como socialmente imprescindible ${ }^{40}$, haciendo de su héroe un verdugo a su pesar, Balzac, a su manera, en un drama más individual que social, lo destaca como universal figura del infortunio y de la soledad, a zaga de otros dos maestros del ochocientos (quienes tuvieron la posibilidad de leer el relato balzaciano): Victor Hugo, en El último día de un condenado a muerte (1829), y José de Espronceda, en el poema "El verdugo" (1835) ${ }^{41}$. Así pues, el motivo de la cabeza cortada

40 Joseph de Maistre, Las Veladas de San Petersburgo o diálogos sobre el gobierno temporal de la Providencia, Valencia, Imprenta de J. Gimeno, Mayo 1832, t. II, pp. 111-114. La edición original es la siguiente: Joseph de Maistre, Les Soirées de Saint-Pétersbourg ou Entretiens sur le gouvernement temporel de la Providence, suivies d'un Traité sur les Sacrifices, ed. Rodolphe de Maistre, J. B. Pélagaud, et Cie, Lyon, París, 1821, 2 vols. La ardiente defensa de la pena de muerte y la apología del verdugo que se leen en Las Veladas de San Petersburgo, dieron lugar a severos ataques contra el conde de Maistre y su idealización del ejecutor. Véase al respecto Jean-Baptiste-Marie Nolhac, $M$. le comte Joseph de Maistre et le bourreau, Louis Perrin, Lyon, 1839.

41 Vid. Victor Hugo, Le Dernier Jour d'un Condamné, ed. Roger Borderie, París, Gallimard, "folio classique", pp. 39-140; y José de Espronceda, El Diablo Mundo. El Pelayo. Poesías, ed. Domingo Ynduráin, Madrid, Cátedra, 1992, pp. 188-191. En lo tocante a la figura del verdugo en la obra de Hugo, remito a Maxime Prévost, "Le monstre et le bourreau", en Rictus romantique, Montréal, Presses de l'Université de Montréal, 2002, cap. I, pp. 49-85; y Stéphanie Boulard, "Rouge: Victor Hugo ou la couleur en perspective”, Polysèmes, [en línea], 14 (2015): https://doi.org/10.4000/ polysemes.1439. Sobre el poema de Espronceda, el cual lleva, claro está, el mismo título que el texto de Balzac (¿̨mera coincidencia?, ¿air du temps?, ¿̇intertextualidad consciente?) y puede leerse como el triste soliloquio y el lamento, lleno de amarga ironía, de un verdugo profesional, véase Russell P. Sebold, "Criminal sin delito: $E l$ verdugo de Espronceda”, en Homenaje al profesor Antonio Vilanova, coords. Marta Cristina Carbonell y Adolfo Sotelo Vázquez, Barcelona, Universidad, 1989, pp. 647-662. Vid. también, Joaquín Casalduero, Espronceda, Madrid, Gredos, 1967, pp. 148-171; y Guillermo Carnero, Espronceda, Madrid, Júcar, 1974, pp. 3038. Para otros detalles sobre la figura del verdugo en las letras españolas, véase Andrea López Pagola, Representaciones literarias en la figura institucional del verdugo español del siglo XIX. Trabajo de Fin de Grado. Tutora: Montserrat Amores García, Universitat Autónoma de Barcelona, 2018-2019 [en línea]. 
se antoja omnipresente en el imaginario del novelista Balzac, el cual ha llenado su obra de testas y de miembros amputados: ¡elemento revelador de un miedo a la castración? Sin pronunciarnos, mencionemos solo el tema del brazo segado en Un grande de España (1832) y el motivo del hacha y de la decapitación en La duquesa de Langeais (1839), hermosa novela (sobre el amor y la vanidad) que Balzac tituló primero Ne touchez pas la hache (1834), es decir: No toque(s) el hacha.

Podría decirse que, de manera paradójica — como a menudo pasa en el espacio de la ficción-, en El verdugo lo más interesante no es lo más evidente, ni tampoco lo que pertenece al (programado) proyecto de escritura y al (anunciado) pacto de lectura. En este caso, lo que cautiva al lector no solo radica en la alusiva historia de familia que asoma en el texto sino también en las señas biográficas que el relato disimula. Apuntemos, pues, cuánto la "novela" dinástica esbozada en El verdugo encuentra correspondencias en la historia personal del escritor. Recordemos, por ejemplo, el cariño, no exento de ambigüedad, que vinculó a Honoré (1799-1850) con su hermana Laure (1800-1871), futura señora Laure Surville y autora de una de las primeras biografías del gran hombre ${ }^{42}$. Pensemos también en que El verdugo fue precisamente escrito en 1829, el año de la muerte, a los ochenta y tres ańos, del padre del escritor: ese Bernard-François (1746-1829), de origen campesino, cuyo apellido era Balssa o Balsa (y Balzac, al parecer, a partir de los ańos 1773-1783). Bernard-François B., hombre taimado y voltairiano, quien tuvo una destacada carrera en la administración, se había casado a los de cincuenta y uno con una burguesita parisina de diecinueve: la futura madre de Honoré. Semejante padre, con aspecto de anciano (¿de abuelo?) pero de personalidad poco común y de novelesca ambición ${ }^{43}$, nuestro escritor lo hubiera deseado de Balzac y no Balzac a secas. Como por casualidad, fue tras la muerte del progenitor, depreciado y envidiado, cuando Balzac escribió El verdugo, su primera historia de parricidio explícito y, en cierto modo, de venganza implícita. Por eso, al firmar El verdugo con el nombre de "H. de Balzac", parece que quiso poner de relieve la brillante partícula

42 Laure Surville, Balzac, sa vie et ses auvres d'après sa correspondance, París, Librairie Nouvelle Jaccottet, Bourdillat \& Cie, 1858.

43 Vid. Jean-Louis Déga, La vie prodigieuse de Bernard-François Balssa (père d'Honoré de Balzac), Rodez, Ed. Subervie, 1998. 
nobiliaria y, de ese modo, ajustar cuentas con una figura paterna sin lustre o, al menos, demasiado bourgeoise y nada aristocrática. No olvidemos que los sueños de nobleza de Balzac le llevaron a firmar sus obras de juventud bajo tornasolados seudónimos (Lord R'hoone, Horace de Saint-Aubin etc.), relegando al olvido el prosaico apellido de Bernard-François. Como bien se entiende, tal delirio de grandeza nominal, tal fascinación linajuda, tan criticada por los contemporáneos del autor ${ }^{44}$, encuentra fuertes ecos en El verdugo, cuyo nudo reside esencialmente en el deseo de preservar un nombre prestigioso, en la conservación a la vez vital y mortífera de un título de sangre.

Al lado del motivo latente del incesto con la hermana y del tema del parricidio, el relato evoca a una madre amante, a una buena madre o "suficientemente buena", por hacer nuestra la sutil, aunque trillada, noción de Winnicott ${ }^{45}$. Esta figura simboliza el reverso, la haz idealizada de la madre de Balzac, pues los biógrafos del escritor han mostrado como nunca se sintió amado por aquella mujer, según evidencia la correspondencia del autor. De ahí, sin duda, el topos del "niño maldito" que corre por los textos balzacianos y, concretamente, en el relato, ya mencionado, cuyo título exhibe el llamativo marbete "enfant maudit" y data del lustro 18311836. En El verdugo, valiéndose de una sugestiva inversión, el autor baraja las cartas identitarias, redistribuye los roles, haciendo lo necesario, en el seno de la ficción, para que Juanito sea al mismo tiempo el hijo favorito y el bastardo potencial, cuando, en la realidad, fue Henri-François (18071858), el menor, el hijo adulterino, el niño preferido de Anne-CharlotteLaure Sallambier (1778-1854), la cruel madre de Honoré ${ }^{46}$.

Como viene evidenciándose y como suele ocurrir en obras posteriores, Balzac se revela tanto como se esconde en El verdugo. En esta obrita, el futuro creador de La Comedia humana, quien pronto se imaginó

44 Véase Charles Gould, “M. de Balzac': le dandysme de Balzac et son influence sur sa création littéraire", Cahiers de l'Association internationale des études françaises, XV, 15 (1963), pp. 379-393.

45 Donald Woods Winnicott, Le bébé et sa mère, trad. Lynn Rosaz, París, Payot, 1992, pp. 19-32.

46 Sobre la huella de esta madre — llamada, en su correspondencia epistolar, "enemiga" y "monstruo" por Balzac — en otras novelas del gran novelista, véase Rose Fortassier, "Du bon usage par le romancier Balzac des souffrances du jeune Honoré", Imaginaire et inconscient, 12 (2003), pp. 39-52. 
secretario de "la Sociedad francesa" ${ }^{47}$, se hace el secretario de su historia personal o petite histoire, el genuino posesor de los secretos de otro grupo, de otra sociedad tan compleja como la grande, pero mucho más íntima y reducida: su propia familia.

Novela tan breve como fascinante, El verdugo es un texto realmente polifacético, un texto-secrétaire ${ }^{48}$, para expresarlo en francés, una especie de texto-escritorio con cajones secretos. Bajo la apariencia de una anécdota verdadera anclada en un contexto histórico muy concreto, incluye sinuosamente el esquema de una doble histoire de famille: la del protagonista principal y la de su creador. Aunque no sea del todo original, esta historia de familia dentro de otra no deja de impresionar, y con igual impresión se consuma la asombrosa muerte que se reserva a la familia ficticia. Por otro lado, esta violencia ficcional, la del sanguinario G..t..r, asumida, por deber, por el verdugo Juanito, acaso oculte otro ensańamiento, nada menos que el del mismísimo Balzac para con sus personajes, como no duda en afirma el escritor Pierre Michon, en una máxima que conviene poner de relieve traduciéndola al pie de la letra:
De la incalificable sencillez de la literatura [...]. Sí. Al final, mueren el viejo Goriot, el hermoso Rubempré, la cálida Esther, la bondado- sa Henriette. [...] El relato solo está escrito para ejecutarlos ${ }^{49}$.

Si admitimos la mortífera lógica dictada por Michon, El verdugo podría ilustrar una voluntad parecida de ejecución textual. En tal caso, por encima de G..t..r y Juanito — los verdugos de papel—, se encontraría otra

47 "La Société française allait être l'historien, je ne devais être que le secrétaire" ("La Sociedad francesa iba a ser la historiadora, yo no debía ser más que su secretario"). Véase Honoré de Balzac, "Avant-propos", en La Comédie humaine, I, op. cit., p. 11. La traducción es nuestra.

48 Del mismo modo que en castellano, en francés la palabra secrétaire puede significar "confidente" y "escribiente", pero la voz también se usa con la acepción de "escritorio".

49 "De l'inqualifiable simplicité de la littérature. [...] Oui. À la fin ils sont morts, le vieux Goriot, le beau Rubempré, la chaude Esther, La gentille Henriette. [...] Le récit n'est écrit que pour les mettre à mort." (Pierre Michon, Trois auteurs, Lagrasse, Verdier, 1997, p. 12). El libro también se ha publicado en español: Pierre Michon, Tres autores, trad. María Teresa Gallego Urrutia, Barcelona, Anagrama, 2006. 
figura, agazapada en las zonas oscuras de lo implícito. Esa figura, por supuesto, no sería otra que la del mismo autor en hábito de victimario frente a sus criaturas imaginadas. Así el "H. de Balzac", la firma autorial y evidentemente incompleta del texto, termina por entenderse en su sentido oculto, ya que en francés la letra h y el objeto hacha, por así decirlo, se pronuncian de manera idéntica ("ache”). En suma, tras la lectura de El verdugo, la inicial del nombre de pila de Balzac acaba por sonar como una hache todopoderosa y como un implacable e imparable hachazo en un tarugo. Dicho de otro modo, El verdugo parece anunciar, de manera ambivalente, es decir de forma a la vez callada y cortante, al titánico Honoré de Balzac, aquel padre de un ciclo sobrehumano, aquel hacedor, muy aventajado, de vidas y de muertes. 